\title{
O Črnem biku ali Čarnem juncu
}

\author{
Joža 亡̌op
}

Spodnje Bohinjske gore se po pravem imenujejo Búkovske planine. Kadar so se možák' skupno s starim Oblačičem (Ârhom), županom srenje Savice, pogovarjali v nedeljo popoldan pod stogom, so se pritoževali, da jih od vseh strani že od davnega stiskajo drugi, da sta bili cerkvi Sv. Janez in Sv. Duh (pravzaprav Sv. Trojica) bukovski, meja pa je šla v Staro Fužino za Vrtovinom po sredi Jezera čez Ukanc, koder je imela srenja tri manjše predplanine z imeni U Rožičovcu, U Mečižovcu in U Oblačičovcu. Podobni planini sta bili še U Zagradcu« in U Strženeh, ki sta bili polanski. Ostalo je bilo »fežnársko«, ki je mejilo na studorsko. Meja med Staro Fužino in Studorom je bila na velikem kamnu, ki je stal vzhodno od Židanove nekdanje kovačnice.

Svet nad Črno goro (1606) in Konjskim vrhom (1879) je bil nekaj posebnega zaradi podnebja, rastlin in živali. Zalisc, Osredki, Črna prst (Ta vlíka Črna gora 1844m), Četrt $(1832 \mathrm{~m})$ so veljali pri domačinih in tujcih kot rajski planinski svet. Povsod je bilo polno planinskega cvetja, in ko sem bil po vojni prvič in zadnjič na vrhu Črne prsti, je bilo tam polno dišečih murk, velikega svedrca ter planik, po skalovju pa burje, da se je bilo škoda kam usesti ali uleči. Sedel sem na kamnu onstran in tostran nekdanje meje in se oziral naokoli, s primorske strani se je čutilo kot dih z morja, s tal pa je dišalo po murkah, kakor da bi Zavrtanik imel tam gori svojo tovarno čokolade. Po pripovedovanju starih je to bil nekak rajski planinski svet, o katerem so obstojale raznovrstne pripovedi o doživljajih in rudnih zakladih. Sem gori so hodili le posamezni znanstveniki in zdravniki iz rudnikov in fužin. Vse to so vedno varovali. Ko sem bil prvič na planini Zalisc, sem imel dolgo palico $\mathrm{z}$ gamsovim rogom na koncu in tja gor sem privezal le tri vejice burje. Prve tri planike $\mathrm{v}$ življenju sem odtrgal po vojni na Črni prsti. Očanci so pravili, da so gori trgali v glavnem le nekaj malega burje, drugače pa le zdravilne rastline. Toda ko je bila zgrajena gori leta 1894 Orožnova koča in se je začel turizem, »so začeli gosposki ljudje trgati cele naročje rož,kakor bi doma imeli kako posebno vrsto boga, ki to na vso moč rado požira. «Še bolj množično pa se je to počelo po razširitvi koče in otvoritvi Bohinjske železnice leta 1906, ker je bil to izjemen planinski izlet za ljudi, ki še niso imeli priložnosti v enem dnevi priti z morja v tako čudoviti planinski predel in se še istega dne po želji tudi vrniti nazaj na morje ali pa v kak drug turistični center ali mesto. Ko je stekla železnica, je nastajalo tudi vedno več primerov, da so na tem območju izkopavali rastline in kopali v iskanju zanimivih kamnin in raznih predmetov. Izkopavanja rastlin s koreninami ter kopanje in brskanje za predmeti pa se je vršilo tako po celem Bohinju že med gradnjo železnice, povečalo po prvi svetovni vojni, po drugi pa se razširilo prikrito v večjem obsegu tudi $\mathrm{z}$ raznimi pripomočki in inštrumenti.

Búkovske goré so nekako na sredini med visoko planoto Komno na zahodu in Jelovico na vzhodu. Na tem območju je cela vrsta gorskih vrhov in med njimi znanih in skriv- 
nih prehodov ter predelov, o katerih je obstajalo veliko odkritih, še več pa skrivnostnih prikritih pripovedi, ki so se prenašale iz roda $\mathrm{v}$ rod le preko posameznikov v obrednem izročilu.

\section{Spodnja Polana pod planino Zalisc in pot v planino Zalisc}

Po mojem prepričanju je bila Spodnja Polana obredni kraj na prehodu dolinskega sveta (»Solzne doline«) v gornji svet (»Svete planine«), podobno kot je ta prehod pri stogu med spodnjim delom in petrom, ali pri stari hiši med hišo (izbo) in zgornjim delom (ispo $z$ déro). Govor je o meji, črti, preko katere je prehod iz enega v nekaj drugega, ki je prvemu različno ali pa nasprotno in zaradi tega v nekakšnem sožitju, kakor je na primer zakonski jarem sožitje moškega in ženske, vprežni jarem ali »štánga« je sožitje vola in konja pri oranju.

Pot v planino Zalísc je skupaj z živino vodila čez »Kamníc« ali »Jbr«čez potok»Strteníco« na Žlán ter »Pod Lúknjo« do višine okoli 900 do 1000 m, koder so imeli Polánci odcep za svojo planino »Osredki« $(1.400 \mathrm{~m}$,»Za Vosréšč «). Pot se je tam dvignila po robu našega bukovega bošta za nekako $100 \mathrm{~m}$, nakar se je zavila proti vzhodu preko strmega pobočja Lisca vse dokler ni tega pobočja zmanjkalo in se je odprla jasa Polane pod planino. Pot preko Lisca se je nekoliko dvigovala, še najbolj na koncu pri dvigu na »Polánco«, $s$ katere se je potem dvignila na rob planine, na katerem je bila Orožnova koča, planina sama s stanovi in »vôkvom « pa je bila po spustu s tega roba. Spomnim se prvič te poti. Vodil sem telička - mladega bikca,ki ga je kot pravo domačo bohinjsko pasmo (rekli so »sórto«) izbral in preskrbel prav »Voblačíčov vôča«, ki je hotel vsaj na Bukovem »postaviti nazaj domačo trpežno sorto. « Na tega je "povóživ svojo roko« - kot je pravil in vedno ga je moral videti, ko je prišel mimo s palico v roki in se vedno vsedel na tnálco in tam "prefetvóv« - to je govoril v to in ono smer ter prekriževal ("prepletvóv") nogi. Tega júnčka je nekako "dal meni v roče". Rekel je, da zato, kar me je krava Róža nabasala na roglje, ko sem bil še v súkenci, in se nisem poškodoval, ko me je zabrisala čez samo sebe. Rekel je, da je to poseben »cáhn.« Vpeljal me je, da sem ga pasel blizu doma ob stezah v Žúpenku in mi s svojo palico pokazal, katere trave in rože naj mu prinašam v jasle. Ni pustil, da bi ga dali v srenjski »telečnek « v Mlako ali v našo ograjeno gmajno ob Šémenci. Na žalost je pozneje, ko starega Oblačiča ni bilo več in je ta junček postal od sile postaven in »brščb kravji fant od fare«, začel nanj pokladati svoje roke eden od mesarskih mešetarjev, kar je bilo vzrok, da so ga spremenili v vola Fígaserja, kar je pa že druga posebno zanimiva zgodba. Junček je bil temnejše rdeče barve, kakor jo ima divji kostanj, bil je nizke postave, na moč živahen in okreten, vesel in priljuden ter žebotastih parkljev kakor gams. Tudi taka zelišča je jedel, ki jih je v skalovju Ród'nce vedno znal poiskati znameniti kozel Vrbaničovega Jurja, kozarja z Broda.

$\mathrm{Na}$ Poljani smo počivali. Prvo so se odžejale v vokvu krave, nato ostali. Eden je stal ob tistem kamnu, mislim, da je bil sivolasi Rožičev Johan s Savice, ki se je spomnil starih, nakar so zmolili za njihov pokoj, za zdravje in srečo vseh živih in enako za živino, ki jo sedaj peljajo na planino »tri češene Marije « in to je bilo vse. Mislim, da jih je samo kakih pet klečalo na eno koleno, ostali so stali. Pot preko Lisca je bila znosna, dvig na Poljano me je zopet utrudil, da sem gledal navzgor in spraševal, koliko je še in, če ne bo že konca. Nad Poljano gori se mi je zdelo, da sega strmina še zelo visoko, bila je delno poraščena in sprva je šlo zelo težko, ko pa smo bili gori, sem pa rekel:«A, smo že tlêle!« ker so se mi noge že zopet vključile v skupinsko hojo - nekakšno romanje. 
Sedanja zgornja gozdna cesta preko Lisca poteka v višini 1100 m. Polana pod planino bo kakšnih 100 m višje. Planina »Zalisc« je v nagibu robu v smeri proti jugu, koder je v dno vókvo, stanovi pa so razporejeni v lahni brežini, ki ni tako strma, kakor je ona na severni strani, to je na Polani.

Tedaj, ko sem bil z mladim júnčkom ali bikcem - poznejšim volom »Figaserjem« - prvič na planini »Zalisc«, je tam stala povečana Orožnova koča. Oče je tedaj šel okoli koče obratno od sonca in jaz sem mu sledil z mladim bikcem čiste bohinjske pasme, ki je bil tedaj še teliček in tudi prvič na planini. Po kratkem počitku spodaj ob »vókvu «smo z očetom in bratom nadaljevali pot na Zgornjo Polanco. Tedaj smo namreč tja gori peljeli le štiri teleta. Očetu se je mudilo, ker je bilo treba čimprej postaviti streho tam gori, koder smo imeli staro pravico pod skalnim previsom.

O starem obredju na Poljani so govorili že takrat, ko sem bil prvič tam z junčkom »ta práve bohinšče sórte«, vendar sem bil premlad in tudi preutrujen, da bi si kaj zapomnil. O tem mi je pozneje pravil oče po delih ob prilikah, ko se je spominjal te ali one reči, ali pa, ko je meni padel v glavo kak delček spomina, pa sem hotel vedeti, kam to sodi in kako je bilo s to rečjo v celoti. Povedal je sledeče: »Tam, koder stoji Orožnova koča na planini Zalisc je bil vógrad črnega junca Skočérja, ki je bil v veliki časti. On je bil tam gori na vardi božjega sveta, ki je nad kamnom na Poljani. Vógrad je biv s kamnov na okroglo, to je breg voglov tako, kakor dela Urša na star način tri flánčneke pri mlinu.

Na planino Zalisc so nas vodil Voblačíčov Vôča. Šli smo od doma, ko je bla še tmá. Zato je šla pred vôčam ta zvončásta dokler ni rátovo svetlo. Potlej so vôča s svojo krivo pálco stopili naprvé pred zvončasto, ki je dobila za lon pest soli in hvalo s pobožanjem. Na Polan so vôča stojé čakal ob kámno, da je prišla na Polano vsa čéda z ljudmi. Čakál' so pred kamnom stoje. Ko so bli vsi gori in se je žváv odžéjova in polégva, so stojé ob pálci imel' besédo, kod smo, da smo na mej' med sóvzno dolino mártranja, kódr nam je služiti, dévati in se potiti za zaslužene rájskega véčnega vesela. Pred nami pa se vzigúje rajski svet planin, koder ni in ne sme bit' nobene pregrehe v ničemer, še najmn pa v uničvánu svetá, ki je božji, ki ga ne moremo narediti, pokončamo pa ga vohká zlo hitro, pa z mávo mújo! Smo kókr na vráth, al' pa na božjem prágo, al' pa pred vúkno pétra, k'se mora vsákdo popréj umislit svojih del na kresáne, da gre sčisan v višavje. Nato je sedu na kámen in med prefetvánam nog, to je križanem ankrat leve, ankrat desne, obrnjen k l'dem in živin, ki je počiváva pa prežvekváva moliv nekakšne stare litanije napré,l'djé pa so odgovárjal' na enáko vižo. Moliv' je napré zatégneno, ko'kr' bi pev. Eni so klečál, drug' pa stal'. Našteval je vmes tudi zelo stare svetnike, tako svétga Lója pa svétga Jóla, kar sem si dobro zapomnil, ker so ta mladi mislili, da je to nekakšen »žmávc« in božja mast, drugo pa rajni stari Bjol, ki je biv zelo pobožen in so ženske videle cáhn, da je šou koj v nebesa, ko so ga djali v svéto vóle.

Ko je bilo to opravljeno, je vstov, si pálco naslonil na ramo, ko se je obrnil k planini in dvignil obe roki, ostali pa so pokleknili vsaj na eno koleno in skušali ponavljati za njim stavek za stavkom neke zelo stare molitve, da bi vse nas - to je ludí in žvíno spustil gori na planino Črni b'k Skočér, ki je na gvárdi božjega, to je svetega svetá, katerega déu je tudi planina in polánce in koder imajo majengo pvanvati, majariti, žvina pa se pasti brez poškodovanja božjega sveta. Prosijo razumevanje, ker drugače ne morejo preživeti ne sebe ne žváli, ker so stiske v sovzni dolini številne in hude, da málokdaj takó.

Prosijo za dobro pašo, pravo vreme, zdravje pri l'deh in živini, zadostnih voda $\mathrm{v}$ vókvah in varstvo zoper strele, silovite vetrove in točo ter prežeče skalovje in prepadne jame.« 
Oče si je zapomnil nepopolno nekaj okrnjenih stavkov in besed raznih izvorov ter tudi take dudleto in nosnike, ki jih je še posebno pojoče zategnil v brenčeči »õn « in »en, « med temi tudi besedo ali vezavo »jenže« in »trapekus« ali »-kos« in kaj podobnega. Ko sem to pravil profesorju Maksu Miklavčiču, sta o tem razpravljala z dr. Antonom Breznikom. Ugotovila sta v besedilu dudlete, nosnike na »o« in »e« ter silno stare ostanke, ki sta jih delila na glagoljaški, zapadnoslovanski in lužiški izvor ter vpliv govora planin Severne Italije. Med sabo sta menila, da gre tu za nekak arheološki besedni kotlič večih dob in plasti, ki jih je potrebno še raziskovati. Menila sta, da so tu lahko še stari ostanki, ker je »trápeksa « predelano v »trápec, « v osnovi pa je to lahko »gostoljubna miza«, »oltar«, "žrtvenik" ali celo prestol Sonca. Razmere, ki so nastajale in vedno hitrejši osupljivi in nepredvideni dogodki v svetu, ki je bil na pragu nove še strašnejše svetovne vojne, je vsa prizadevanja $\mathrm{v}$ številne, tako zelo potrebne smeri, preprečila.

Oče je še pravil, da so potem, ko so se vzdignili z živino na rob, to najprej »navižali s soljo« okoli vográda, kamor je navadno »ta zvončásta« sama šla, potem pa so se lotili dela pri stanovih in sirarci. Ko so delali na planini, je skupina odbranih fantov z gorjačami in palicami naskočila robovje $\mathrm{z}$ vpitjem, razsajanjem in tepeškanjem po skalovju. Z reškanjem in tepeškanjem, so preganjali Trápa ali Trjápa, to je Jáplna. Ko so dosegli robovje planine, so se vrnili »naokrog «, to je »v zasúku s prepletom«. Po vrnitvi so fantje bili pogoščeni in šele takrat so po starem smeli odgnát teleta na Polance, ki so tri in vsaka ima "vókvo« (Spodnja, Srednja in Zgornja Polanca se dvigujejo iz dna planine v smeri Velike Črne gore). Če seštejemo to, kar sodi skupaj (Spodnja Polana, planina »Zalisc« in troje Polánc), dobimo sveto število »pet« $(5, \mathrm{~V})$.

Že oče je pravil, da je bila razlika med pogonom izbranih fantov z gorjačami tedaj, ko je vodil odpravo v planino Zalisc stari Oblačíč še tedaj, ko ni bilo Orožnovega doma, od tistega, ki je bil pozneje.

Po tedanjem opisu je bilo pet izbranih fantov, ki so lazili in poletavali po nekakšnem prepletanju, udarjali so $\mathrm{z}$ gorjačami po skalah in robovju z začetno razmaknitvijo, napredovali poševno v bregove, kakor hitro se je prvi približal drugemu, da ga je dohitel, sta nehala udarjati in eden od njiju je prvi spremenil smer, da nista trčila skupaj. Ko so dosegli neko višino, se je prepletanje obrnilo postrani na vračanje v dno, koder so se vsi zbrali na nekakšni pogostitvi, seveda ob ognju.

Pozneje pa je bila nekakšna parodija, pravi pogon ali preganjanje nečesa do trdega mraka in razgrajanja in novinec, ki je vzel resno ter zašel previsoko, je ostal osamljen. V mraku in nazadnje $v$ temi je blodil nazaj v nižino, kamor so ga vabili klici za pogrešanim. Toda spodaj v temi jih je dobil s palico po riti ali hrbtu ob pojasnilu: »Ti si tisti tráp, ki ga lovimo in iščemo! »V tem primeru je tráp = zatrapánec, cépec. »Tráp « v tej vrednosti je tudi v púnco zatrapán fant, ali pa tele, ki zagléda nóva vráta. Tráp je bil tudi tisti, ki je ropotal s cokljami.

Na tretji ali Zgornji Polanci ima posest Savica - Kamnje št. 15 (sedaj št. 1) zelo staro pravico do uporabe prostora pod skalnim previsom na Zgornji Polanci tam, kamor posije jutranje sonce. Pravili so, da posije jutranje sonce tja iz smeri vógrada Skočerjevega. Jama ali skalni previs je v pobočju Kozjega hrbta, ki je vez med Črno prstjo (Veliko Čarno goro $1844 \mathrm{~m}$ ) in Liscem (Liso goro 1649 m). Od Četrta (Šetrta $1832 \mathrm{~m}$ ) ločijo ta hrbet Vrata. Dokler ni bilo Orožnove koče, je vse skupaj predstavljalo povezano enoto in četudi je prišel gori kak planinec, se je ta vključil v planino. S postavitvijo koče pa se je to zaradi razširitve planinstva na turizem razdvojilo, ker je postal v tem koncu turizem pomembnejši, 
planšarstvo pa nekaj zastarelega in podrejenega. Spominjam se petero vókvov, od teh je prvi izginil tisti na Spodnji Poljani na dohodu - vsaj zadnje leto pred vojno se ga več ne spomnim. Bil je itak manjši in, ker ga niso vzdrževali, je izginil. Ostali štirje pa so še bili. Tisti od planine je bil nižje od stanov, ostali trije pa vsak na svoji Polánci. Izgovarjajo »tist' vôkvo« v moški in ne srednji obliki.

Takrat prvič je šel poleg očeta tudi stareǰ̌i brat Janko,ki je imel drugo delo. Pomagal je pri prenosu drugim, nama pa se je pridružil, ko smo se napotili na Zgornjo Polanco. Jaz sem pazil na teleta in gledal, kako delata ter le včasih kaj poprijel. Oče je najprej pregledal, če je vse pod skalo zloženo in zavarovano, kakor je treba in o tem tudi podučil. Nato sta vse zložila izpod skale in razvrstila po tleh v bližini.

Prvo se je lotil postavitve strehe za ognjišče, to je šopa s petimi trami v nekakšni pahljači. Ko je bilo to napravljeno, se je lotil večje strehe, ki je imela obliko daljšega pravokotnika. Tudi ta je imela pet šper - vendar vzporednih.

Obe strehi sta imeli nekaj naklona semkaj od skale tako, da je bila streha oprta pod previsom in je prestrezala tudi tisto deževnico, ki bi jo veter vrgel ob skalo. Nekaj opor je bilo pod robom skale ali v odkrušku robu spodaj, nekaj pa je bilo tudi pripravnih skalnih stebrov, vse druge opore pa so morale biti lesene. Ogrodje je bilo treba postaviti trdno in povezati. Nato so bile gori razvrščene vrste skodel - to pa je bilo še zavarovano in obteženo s kamni.

Predno sta pričela z delom, je oče pazil, da je bilo vse razvrščeno tako, kakor se je po vrsti rabilo. Potem je še podučil, da je treba podirat v obratnem redu in to po vrsti zložiti jeseni pod skalo ter zavarovati.

Oče je povedal,kako je z bratoma pomagal pri razdiranju nekdanje Pántzove žičnice v Ukancu, nakar jim je bilo dovoljeno uporabiti les korpeljnov. Tega so ročno prenesli naokoli in ga uporabili na Bukovskih planinah. Po prenosu je vse lesovje zaznamoval s starim znakom fužine za jeklo - ||| in resonančen les -

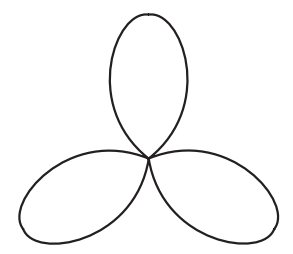

Za to je obstajalo bronasto kvádvo (=kladivo, podobno je še sedaj za žigosanje lesa), ki ga je nekdo odnesel. Zato je naredil obliko žiga iz debele bakrene žice, to segreval na ognju pod malo streho, ta znak pa vžigal v skodle. Ostali les je označil s tremi risi s sekiro ali žago. Znaku za skodle je pravil »deteljica Frtuna«, v resnici pa je bil to triglavski znak ženskega principa, ki je res "tripič" ribe Faronike ali Fortune, to je njenega repa. Lik je isti, kot je bil na starih gumbih (knôfih) narodnih noš.

\section{O ajdih, Orožnovi koči in njeni vidnosti}

Leta 1894. so na ográdu ("pôngradi", "pân-gradi") postavili Orožnovo kočo. Pred vojno je bilo kočo videti izpred naše in Ájdčove hiše (tedaj Kamnje št. 15 in št. 19). 
»Ájdči« so se pisali Repinc, živeli so v skladu z božjo naravo, vestno obdelovali njive, pleli travnike, pometali ulico in »cárski drum « - tako je rekel neki žandar banovinski cesti - popravljali gozdna pota in celo staro rudarsko samotežno pot z Ródnce, koder so nakupili zemljišče Hlipove hiše iz Stare Fužine (nekdanjih starih Várlov, poznejših Gašperinov). V letih pred drugo svetovno vojno so vso živino razen »vôva« dajali v planino Zalísc in eden njihove družine je bil celo poletje gori, skrbel za živino in delal (médel) maslo. Vsak drug dan so to nosili domov pa tudi mleko, ker je to bilo najbolj zdravo. Gospodar Bávant je večkrat rekel, da je v mleku krav iz gmajne megla pa bolezen. Slednje tudi drži. Bohinj je bil določen kot naravno zdravilišča glede jetike. Bolniki so hodili okoli in večkrat pljuvali kri med sprehajanjem po travnikih, rovtih in gmajnah.

Ajdči so imeli dogovorjeno signalizacijo s planine Zalisc in to z gánka Orožnove koče. Izobešali so gori rjuho ali blago različnih barv. Doli so nosili tudi sirotko, púter pa so imeli zavit v sveže liste šávja in v prt.

V »Ilustrirani zgodovini Slovencev« (MK 1999, str. 279) je fotografija prve Orožnove koče ob otvoritvi leta 1894. Zapisana je kota planine z imenom Lisec pri $1346 \mathrm{~m}$. Slika prikazuje leseno kočo, ki ima spredaj verando na tri okna. Streha je brez šopa, je dvokapna, skodle pa so v šestih vrstah (2x3) na vsaki strani. Navadno je pri strehah na obrednih točkah na koncu šop, ki ga je pri lesenih strehah možno napraviti. Pri stanovih so ga opustili, ker so manjši in, ker je bilo vedno težje za primeren les, na območjih planin pa je bilo to še posebno važno. Posnetek na novo kočo je napravljen nekako z jugovzhodne strani proti Črni prsti. Važna je smer slemena, ker je to verjetna os nekdanjega obrednega »ógrada«. O isti koči so bile izdane tudi barvaste razglednice $\mathrm{z}$ nasprotne, to je severne strani ter naslovom »Orožnova koča 1346 m - Triglav 2863 m« in to tako, da je Triglav prav na začetku slemena nad verando.

Leta 1906 so Orožnovo kočo povečali, ker se je v zvezi z železnico povečal tujski promet. Izletniki iz Ljubljane, Jesenic, Gorice in Trsta so zato lahko bili v istem dnevu doma, na Črni prsti in v Orožnovi koči, ali pri Jezeru in slapu Savici. Med drugo svetovno vojno pozimi je koča pogorela. Po vojni so pravili, da se je gori na pohodu ustavila četa Prešernove brigade, ki je po odhodu vse pogasila s snegom, zagorelo pa da je pozneje zaradi vetra, stari pa so rekli, da bi na tistem svetem prostoru gori lahko bila kvečjemu kaka cerkvica, ne pa grešna koča in, da je požar verjetno bil po božji volji in prerokbi.

Orožnovo kočo so morali imeti za nek ajdovski kraj, ker je bilo gori neko žegnanje z mašo in godbo, ki je igrala pri Orožnovi koči, kar se je videlo in slišalo doli v dolino. To je bilo vletih gospodarske, duhovne in politične stiske in trenj pred drugo svetovno vojno, ko je šlo vse na vse strani v ekstreme in so nastali časi, za katere je rekel gospodar Križa in Zéčjega Grádca, »da so prišli cájti krivih prerokov, o katerih govori sveti Matevž, pa da dobiva laž vedno večjo vrednost, pošteno delo pa vedno manj. Zemljo, ki je božje delo, preklinjajo, namesto da bi jo obdelovali in bili na njej z veseljem in zahvalnostjo! Zmerej več je videti navadnih in kronanih oslov! «

Bil je hud, ker je nekdo tudi za »Ájdča«, njegov Križ in Zajčji Gradec med vsem ostalim našteval, kaj vse je ájdovsko v Bohinju. Za »Ájdča (Kamnje št. 19 - eden pa je v Češnjici podobno ob cesti) se je potem umirilo, ker so to bili verni ljudje, nadvse pridni in pošteni, zato nikakršni brezbožni Ájdje. Tudi je verjetno pomagala razlaga, da je hišno ime od »vojvoda«, verjetno pa presukano iz »Ajčija«, človeka, ki rad »ájčka« ali »ájčika«, ti pa res nimajo elektrike in hodijo s kuram spat. Glede »Križa" pa so se tisti, ki so delali 
na Jesenicah, smejali in govorili:« Vsaka bába, vsak dedec ima pod križem ret, potlej bi morali tudi te žegnat!«

Ko sem bil tik pred vojno na planini in hotel vedeti kaj več o prostoru, koder je tedaj še stala Orožnova koča, ter vedeti kaj več starega izročila o vsem tem, mi je star majar s palco zarisal sledeče like

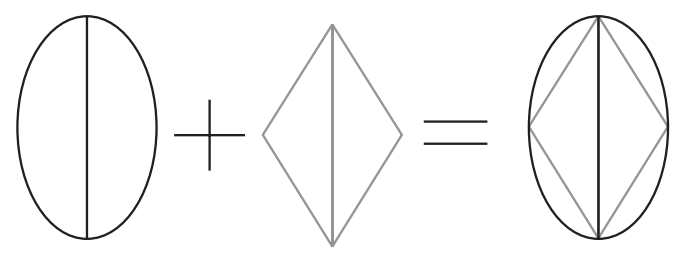

in rekel: »Vidiš - to je to, napré se pa sam brihtej!« In sem se res »brihtal«. Tisto, kar mi je zarisal, kar drži. Ni znal dopovedati z besedo. V resnici je to prikaz družitve dveh nasprotnih elementov, obredno bi to bila sveta poroka med Črnim ali Čarnim bogom in Črno boginjo - bikom Skočirjem in kravo Báuho.

Beseda ali ime za »Črnega junca«, to je »Č́arnega bika«v obliki Skočir, ki se je verjetno v starih časih prenesla na skupno veliko kmetijo »Skočér « in »Andréjevc « na Savici (leta 1826: Urb. No 935 Savica No 13 + Urb. No. 932 No 14), ki je bila zadolžena za vzdrževanje »obrédnega vógrada «na planini Zalisc ali mogoče celo za vodenje celotne planine, je lahko starega izvora, ker je v besedi staro jedro "kók" ali "kúk".

\section{Očetova pripoved o bohinjskem planšarstvu}

(Sestavljeno 2. februarja 1970)

Oče Čop Janez je bil rojen leta 1887 na Kamnjah. To je bila stara železarska družina in rodbina, ki jo je Cojz poklical na delo v bohinjske fužine. Ded Jernej je bil rojen $\mathrm{v}$ Plavškem rovtu in je bil nadkovač v fužinah na Bistrici, ded po materini liniji pa je bil Andrej Rožič (24. 11. 1829 - 12. 4. 1883), ki je bil modelni mizar - mojster, risar in konstukter v isti tovarni. Oba sta bila delavska zaupnika in sodelovala pri sestavljanju in podpisovanju pravilnikov in delovnih redov Cojzovega podjetja. Iz zapuščine Andreja Rožiča so se ohranile edine skice in načrti nekdanjih Cojzovih fužin v Bohinju. Po uničenju fužin v Bohinju so se morali Čopi izseliti. Večina jih je odšla na Jesenice, [trije] celo v Zenico [in eden v Ameriko]. V Bohinju je ostal le Pavel, ki je tedensko hodil peš čez Pokljuko na delo na Jesenice, ob nedeljah pa se je vračal zopet k družini v Bohinj. Tedaj še ni bilo železnice. Pavel se je namreč priženil na Kamnje št. 15 (k»[Spodnjemu] Švigeljču«). Za ženo je namreč vzel Marijo Rožič, ki je bila edini živeči otrok Andreja Rožiča.

O bohinjskem planšarstvu, kravjereji in ostalem je v dneh 28. do 30. I. 1970 povedal sledeče: "Pri hiši smo imeli krave s sledečimi imeni: Véjzejna (to je bila pridna krava), Séka, Bísterna, Líska. Slednja je bila zelo majhna krava, teleta smo dobili pri Oblačiču na Savici. Najraje je jedla plevel, posebno divji radič. Bila je skromna krava, imela je veliko mleka. Še najbolj je bila podobna nekdanjim bohinjskim kravam, ki so bile majhne. Z drugo domačo živino so jo vzeli Nemci, skozi Štenge pa jo je gnal tisti Jakopčev Korel, za katerega so pravili, da je cesarjev sin. 
Volu je bilo ime »Fígaser« (=ki serje fige). To ime so mu dali drugi še kot teletu. Kot vol je imel navado, da jo je tudi s polnim vozom ubral za kočijo. Hotel se je enačiti s konji. Gospodje v kočijah so bili vedno zelo presenečeni, kadar je Fígaser hitel za njimi, To je bilo smeha in splošne zabave! Na ime »Fígaser « je razumel. Če je skočil čez plot, je bilo treba samo zavpiti njegovo ime malo bolj ostro pa se je pognal nazaj. Pri hiši smo imeli le bolj govejo živino, nekdaj tudi dve kozi. Eni od koz je bilo ime »Trákša.« Ker je most na hlev strm in, ker je pot do travnika na Senožetih in do gozdov strma, potem zaradi furenge lesa in drv, je bilo treba imeti pri hiši močnega vola. Dokler ni bilo take vožnje, smo imeli konje, kmalu po prvi vojni pa je bilo vse več težje furenge, zato je bilo treba napraviti vola.

Včasih so rekli, da ni vsak za kozé. Če hočeš kózo dobro pomozti, naredi takole:

Obuj škornje, vsedi se kozi pod rep, kozje nogé si zatakni za štibale, z zobmi jo primi za rep, $\mathrm{z}$ brado ji zamaši rit, potem molzi z obema rokama $\mathrm{v}$ žehtar, ki ga stiskaš z obema nogama! Za to opravilo ni vsak pripraven. Mora imeti tudi primerno brado in, če ima kdo tako brado, rečejo »Ta jo pa ima kot nalašč za kozjo r't!«

Bistričani so oponašali Oblačičovega očeta s Savice, ki je vedno molil naprej ob raznih prilikah (pri procesijah, umrlih, na romanjih, ko so šle krave v gmajno ali planino), to nele navadne, ampak tudi druge zelo stare in včasih nerazumljive molitve. Molil je naprej s posebno pojočim glasom. Za stavek»Kje devica za nas rodiva!« so ga oponašali:»Kje devica u Seu rodiva! « (Opomba: Seu = Selo, to je travniško pobočje, ki pada z jugovzhoda proti Bistrici. To je sosednji predel Ajdovskemu gradcu in spomin na prvo slovansko naselitev v Bohinju.) Od silno starih molitev si je še zapomnil stavek: »Jbnži jezuh na nebesoh da bondet wola twoja!« Stari ljudje so pravili, da je molitev še od Sv. Cirila in Metoda.

Kráve ali kozé je pasel čédenk. Pravijo, da čédenk páse čédo. Pomagal mu je tretívnek. Tretiniti se pravi pomagati pri paši in sirjenju. V Zgornji dolini pravijo »tretínek« in »tretinjêk. « Tretinilo se je za vsako kravo po en dan, šlo je po vrstnem redu, če je eno leto zmanjkalo dni, so nadaljevali naslednje leto tam, kjer so poprej končali. Tretívneka je oskrbela hiša (dala svojega, ali najela póba drugod).

Čédnk in tretívnek sta dobila zajtrk, za s sábo pa hrano (kruh, klobaso, zasko, sadje). Vodo sta si preskrbela v gmajni, kjer so bili studenci. Studenca so pastirji posebej ograjevali in delali žlebove, da ni mogla krava do njih. Spodaj ograje je bila kotanja, kjer so lahko pile tudi krave. V petkih se ni smelo jesti mesnega, zato so že v čatrtkih porabili vso zásko in mesôvje, kar je bilo predvideno za dva dni.V planinah je bilo zaradi tega v četrtkih tako zabeljeno, da so žganci kar plavali v masti in ocvirkih, poleg tega pa so májarji in čédniki pojedli v četrtek tudi suhega mesa (prekajenega surovega ali kuhanega) kar za dva dni, da so se podprli za naslednji dan, ki je bil post, a jih je čakalo naporno delo. Prepoved so spoštovali, ker je bilo tako ukazano. Bali se niso greha, ampak nesreč in hudega, v kar so vérvali, da jih lahko zadene, ako se ne bodo ravnali po zapovedih in pridigah. Kjer ni bilo izvirov, so dobili deževnico v zajedah in kravjih štopnjah, v visokih planinah pa so tajali sneg ali led, ki so ga potegnili iz jam (taki jami pravijo »rúpa«).V rupe so shranjevali tudi meso poškodovanih in zaklanih krav, v bolj skrite pa tudi odrte gamse.

Pastir in tretívnek sta zvečer še jedla posebej. Gospodarji so v planino pošiljali »kéšt « (moko, zabélo, sol, vžigalice, tobak, kašo in jéšprenj ter krompir). Fižola in boba na planinah niso marali, posebno visokih, ker se jim ni hotel skuhati. Priložili so tudi vžigalice, tobak in cigarete (če pastir ali sirar oziroma majar ni kadil fajfe).

Čédnk je bil toraj v dolini in tudi po planinah. Ako ga ni bilo in je bila žival brez mleka, so jo zaganjali, potem pa jo po medsebojnem dogovoru hodili gledat od časa do 
časa. Majar je le oskrboval krave v stajah, jih čistil in molzel, skrbel za mleko, sam sirir ali médel maslo. Vsaka večja planina je imela sírarco in sírarja. Temu je bilo treba pomagati. Vsak dan je eden májarjev pri njem tretinil.

Čop Janez je majaril za Liscam leta 1900 in 1901. Sirar je bil Bleščkov Joža, en majar mu je pomagal pri sirjenju, en majar preskrbel drva za sirarco, ostali majarji delali záse. Čednk pa je bil Arh Andrej (stari Oblačič). V čredi je bilo 105 krav in čez 30 telet, poleg tega pa tudi okoli 15 prašičev, da so pojedli vso sirotko. Prašičem so kuhali tudi šavje in s tem tudi izboljševali planino. Takoje bilo tedaj Za Liscam okoli 10 do 12 ljudi (1 sirar, 1 čednk, ostali pa majarji in majarce). Vsak trop je imel po en močan zvonec, ki se je iz Zalisca slišal včasih celo $\mathrm{v}$ dolino.

Ko so prišle krave v planino, smo jih prvi dan zaprli v ógrade in staje, da so se odpočile. Mi smo pospravljali in razporejali ter pripravljali stan in sirarco. Drugo jutro smo gnali krave v Plano. Tam je vodil molitev stari Oblačič. Molitev za duše, ki po gorah in vodah ter gošah vicajo, je bila obvezna. Prvi paši so bili prisotni vsi majarji. Tudi naslednji dan so šli majarji s kravami, vendar so se lotili vseh potov in steza. Očedili so pota in pobrali vse kamenje, ki so ga tja spravila neurja, plazovi in nalivi. Za pašo je veljal stari ustaljen red, to je, kdaj se žene v eno stran in kdaj v drugo ter, po kakšni vrsti in koliko časa na vsakem mestu, planci, pobočju ali polici.

Stari majarji so znali tudi neko igro. Preganjali so zle duhove, letali s koli naokrog, udrihali vsepovsod, vpili, kričali, vihteli kole in udrihali z njimi po grmovju in kamenju. Ta igra se je razlezla zelo na široko in v njo so vpregli mlajše majarje, novince pa speljali zelo daleč v hribovje, potem pa se jim neopaženo umaknili in se spretno vrnili nazaj k stanovom. Tej igri so rekli »Gremo trápa lovit. « Novinci seveda niso vedeli, kaj je to, pa so ga lovili in podili s svojimi mladimi močmi zelo zagnano in v velike daljave. Tisti, ki je prišel zadnji ves upehan in onemogel k stanovom, je bil za vso drugo druščino »trap."

Kvaníca $=$ prednji prostor $\mathrm{v}$ stanu, ki je na planini. Tam je na eni strani svinjak, na drugi pa so zložena drva in dračje. Mogoče je to od »skladovnica."

Bohinjce je učil sirjenja Švicar Tomaž Hitz. Največ učencev je bilo s Savice in Broda. Búkovska srenja je tedaj zgradila novo mlekarno ali sirarco na Savici z namenom, da bi tam nastala mlekarska in sirarska šola, oblast tega ni podprla, ljudje z Zgornje doline so povdarjali, da imajo oni glavne in prave planine, torej kaj takega pristoja njim, Bistrica tudi, da je pri njih glavni kraj in središče Bohinja, pa je potem vse skupaj padlo v vodo.

Pri Zgornjem Švigeljčo [Kámnje 36] so imeli krave, ki so se zelo dobro vedle. Zato so bile vodnice za vso čredo. Ko je bilo treba v planino, so postale nestrpne in, ko neko leto niso takoj odšli, ker niso bili stanovi pripravljeni, so jo te krave same popihale v planino. Nenadoma so se izgubile in tisti, ki so šli v planino pripravljat stanove in popravljat strehe na njih ter na stajah, so se zelo začudili, ko so dobili krave v planini. Bile so tako hitre, da so prišle pred njimi. Kravam je prijal planinski zrak, posebno pa prostost in planinska paša. Zato so tako rade $\mathrm{v}$ planinah.

Kadar je bilo treba spraviti krave v planino, je bilo treba vedno pravilno postopati. Vse je bilo odvisno od sestava tropa ali čéde. Čednik je vodil ali gnal »ta zvončasto«, mogoče edino še tisto, ki je bila po veljavi takoj za njo, potem pa je šel cel trop. Krave so se same razvrstile, če so bile vajene. Ako je hotela katera imeti neupravičeno prednost, jo je druga opozorila z rogli, če ni vmes posegel kateri bikov ali volov, ob hujših nesoglasjih pa majar.

Zanimivo je klicala Oblačičova Špeva. Imela je čudno razklan ali počen glas. V planini je imela prašiče. Spustila jih je, ti pa so rili po šavju naokrog in se končno ustavili 
ob vokvu v kotanji »Spodnja Polanca«. Tam so rili in se valjali, pihali in prhali ter veselo krulili. Bilo je več kot deset minut daleč in vsi so menili, da bo prašiče težko spraviti nazaj. Tedaj pa je zaklicala Špeva s svojim preklanim glasom: »pôjs, pôjs, pôjs...!« Prašiči so plahutali z ušesi in jo ucvrli s kruljenjem za glasom. Kaj hitro so bili pri stanovih.

Čédnk, májarji in tretívnek - vsi so klicali krave z zateglim glasom, vsak po svojem načinu, kakor so bile krave vajene in, kakor je bilo potrebno, da se je glas bolje slišal in razločneje odmeval v kotlinah in od skalnatih sten gorovja.

Zvonca »ta zvončastih « krav so bila zelo velika in težka. Nekateri so bili tako veliki, da so bili že skoraj zvonovi in ne zvonci, saj so bili veliki ko žehtarji, v katere so majarji mozli. Zvonce so delali v Gorjah. Ker so bili težki, so jih májarji čez noč kravam snemali. Ko je májar mozel ta zvončasto kravo cele črede, je rajni Prangarjev Jaka ukradel zvonc, ki je bil snet. Previdno ga je prijel in šel z njim v mrak, potem pa začel z njim zvoniti, kot bi se krava pasla nekje ob robu kotline. Ko je majar Cengleč Lenart, ki je pravkar mozel kravo, zaslišal njen zvonec, je čisto pozabil, da ima kravo pred seboj, celo to, da ji je pravkar snel zvonec. Medtem ko jo je molzel, jo je klical in, ker ni pomagalo, je zgrabil žehtar in z njim togoten (=jezen, razdražen) priletel izpod stanu, kjer so bile krave.»Rôža, Rôža, Rôža ... ti kôder, kam boš šou! « Jaka je res po kravje pricingljal nazaj in vsi majarji so se smejali.

Ko se je pojála Skočerjova krava, je tri leta star volič skočil celo na streho staje in je bila nevarnost, da se ta udere. Zato so pozneje dajali vole drugam.

Pravi čednk ima krave tako navajene, da jim samo pravilno požvižga in pokliče ta zvončsto kravo (»Cika.. naaa.. naa.. Cika.. naa!«), pa pripelje trop z roba. Tudi pri paši po rovtih in travniki so se takoj obrnile, če si jim pravilno požvižgal,jih poklical po imenu ter jim zateglo zaklical po načinu, ki so ga bile vajene. Seveda jih je bilo treba tudi nagraditi s soljo in to po zaslugi. Nikdar pa nisi smel biti z živaljo krivičen in jo opehariti. Kdor je pri živali izgubil zaupanje, tega niso več ubogale.

Ako so se nakatere krave pójale in ni bilo junca, je bila nevarnost, da poskočijo na čednka ali majarja in to čisto nenadoma od zadaj ter ga s svojo težo pomečkajo, zbijejo na tla in ga polomijo.

\section{Biografsko dopolnilo}

(Sestavljeno 25. V. 2006)

Jernej Čop, rojen 28. VIII. 1819 v Plavškem Rovtu 55 (»Pri Štefonu«), poročen z Elizabeto Ravnik, rojeno 17. X. 1825 na Bistrici 66 (»Ivánova«), nadkovač vseh Cojzovih fužin. Stanoval v »Gospodovi novi hiši« (Bistrica 77, lastnina »Zois«), pozneje kupil hišo 57 ("Prímček"), zato imel domače ime »Primček« ali »Ta máu Jêrn«. Jernej umrl 30. IV. 1899 na Bistrici 57, žena Liza istotam pred njim dne 12. II. 1890.

Pavel Čop, sin Jerneja in Elizabete, rojen 25. I. $1855 \mathrm{v}$ »Gospodovi novi hiši« (Bistrica 77), poročen z Marijo Rožič, hčerjo Andreja, rojeno 5. VII. 1864, dne 19. V. 1883. Marija umrla 10. VII. 1900. Pavel umrl 15. VI. 1912 (Kamnje 15). Pri hiši imajo original skupinske fotografije odlikovancev po končanem železniškem predoru $\mathrm{z}$ župnikom Pibrom $\mathrm{v}$ sredi. Pavel Čop sedi prvi na levi (glej tudi str. 104 v knjigi: T. Budkovič, »Vzpon Bohinja pred zatonom Avstro-Ogrske«, Celovec-Ljubljana-Dunaj 2004).

Andrej Rožič, rojen 22. XI.1829, Kamnje 15, umrl istotam 12. IV. 1883, hodil v šolo pri Cojzovem gradu, nato v Celovec. Vodja modelne mizarne, mizarskih in tesarskih obra- 
tov ter vodnih naprav Cojzovih fužin. Je sin Neže Žnidar (rojena 6. I. 1809) in Gregorja Rožiča (rojen 6. III. 1800) ter gospodar hiše Savica-Kamne 15, bivše tovorniške oštarije na Kamnjah in dveh mlinov in kovačij zgrajenih v ruševini fužine Šemine pod Ród'nco (1/3 kmetije 1849). O Andreju: A. Struna »Vodni pogoni na Slovenskem«, Ljubljana 1955, str. 358-359.

»Oblačičc Savica 12 (kmetija), hišno ime po nekdanjih Oblakih. Župani srenje Savica (cela kmetija 1849). Hiša imela poseben županski štibelc s skrinjo arhivov, kar so mladi pokurili na grmadi v peči v času od 13. do 15. aprila 1941. Ob sporočilu z Bistrice, da Italijani preiskujejo hiše, podtikajo ob preiskavah patrone in papirje (slovenske, nemške in srbske) ter delajo sezname za selitev v italjanska taborišča zato, da bi v Bohinj naselili Italijane. Italijani so imeli že popolen seznam hiš z vsemi potrebnimi podatki o narodni, politični in verski pripadnosti ter odnosu do Italijanov.

Gospodar 1826 Janez Arh

Gospodar 1849 Gašper Arh, rojen 2. I. 1797 Češnjica 59

Kako so si sledili gospodarji in srenjski župani srenje Savica, bi se dalo ugotoviti. Zadnji župan Oblačič (Arh) je bil nizke čokate postave in se ga dobro spominjam, ker me je oče vzel s sabo, ko je v tisti njegovi pisarni z njim pregledoval papirje in mape. Ta se je tudi večkrat oglasil pri nas in vedno sedel na tnalco in med govoranco (»prefetvánam«) prekladal prekrižani nogi. S sinom Janezom, ki je od rojstva bil brez roke, gospodarjem pred zadnjo vojno in čebelarjem sta na skupinski fotografiji Bohinjcev, ki so šli na Dunaj, poklonit se cesarju Francu Jožefu pod vodstvom poslanca župnika Pibra Janeza. Pred zadnjo vojno je bil župan srenje Janez Žmitek p.d. »Píntar«, Kamnje 29.

(Uredniški pripis. Zgornje besedilo je 12. IV. 2006 izzval obisk Toneta Cevca pri avtorju. Etnološki komentar k obredu na Polani sta tako članka: Tone Cevc, Arheološki dokazi o pašništvu v Alpah, Zbornik "Človek v Alpah", Ljubljana 2006; Tone Cevc, Verovanje v Alpah, Zbornik "Človek v Alpah", Ljubljana 2006. Glasbenonarodopisni inštitut ZRC SAZU, Ljubljana, hrani mnogo starejši avtorjev zapis očetovih spominov, ki ga je avtor poslal že leta 1970. Ker pomembno dopolnjuje osnovno pripoved, ga objavljamo kot drugi del prispevka. V oglatih oklepajih so poznejša avtorjeva dopolnila.) 